\title{
Poverty and it's Alleviation: Lessons for Nigeria
}

\author{
*Kalu E. Uma, Paul C. Obidike \& Frank O. Ozoh \\ Federal University NdufuAlikelkwo, Abakaliki, Ebonyi State, Nigeria
}

\section{ABSTRACT}

The study focused on the persistent poverty status in Nigeria in spite of all the actions and activities directly and indirectly put in place to reduce it. Nigerian poverty statistics and government actions in tackling poverty were examined. Few countries that have succeeded in reducing poverty position were briefly examined. Specifically, we highlighted how Malaysia, China and South Korea aspired and attained high level poverty alleviation. The lessons of their success stories were the basis for recommendations for Nigeria as a panacea for poverty reduction which has persevere in spite of every efforts over the years. Among the recommendations made include: designing of poverty line for the entire geopolitical zone, stating target of poverty reduction within a time frame, and sincerely implementing and monitoring of strategies, programmes and policies.

Key words: Alleviation, inequality, lessons, poverty, practical

\subsection{Introduction}

Since after the independence of Nigeria in1960, there have been myriad of problems ranging from low income, high unemployment, insufficient capital overheads, poor infrastructure, lack of relevant institutions like banks inclusivity, particularly for easy access to credit facilities, poor governmental institutions, low access to medication, insufficient and poor quality training centres, improper management of societal resources amongst others. This situation has persisted in spite of various development plans and programmes aimed at changing the ugly trend. It has hampered the expected degree of human and capital development and environmental restructuring needed to overcome poor living standard. Consequently, Nigeria as the most populated region in
Africa is wallowing in abject poverty in spite of its abundant natural and mineral resources endowment.

Besides, the level of inequality that have been during the colonial era gradually rosedue to majority engaged in subsistence agriculture, lack of industries and the actions of the privileged few at the helm of affairswidened the gap between the poor and the rich. Studies by Kolenikov and Shorrocks (2003); UNU/WIDER (2000); Addison and Cornia (2001);Canagarajahet al, (1997); Kanbur and Lustig (1999) have shown the prevailing income inequality in developing countries in general and specifically in Nigeria which has contributed significantly to poverty situation. This income inequality is reinforced by actions of leaders and those closer to power that diverts societal resources for personal use, and as such deny the masses .of the benefits accruable from the distribution of national income. Unbelievable, in 1996 and 1997, Nigeria was ranked one of the most corrupt countries in the world with corrupt perception index of 0.69 and 1.75 respectively (Transparency International, 1996,1997). But in 2009, 2010 and 2011, the corruption perception indices for Nigeria were respectively 2.5, 2.4 and 2.4. The World Bank (2012), stated that the poverty headcount of Nigeria is $62.6 \%$. Poverty has really been raised by the actions of the leaders with respect to myopic perception and corruption.

The realization of the role of income inequality in developing countries as the major cause of poverty has been the propelling factors of policy makers to design programmes and policies aimed at closing the gap. The aspiration to ensure a decrease of income inequality and increasing the living standard led to various micro and macro approaches to poverty alleviation programmes in Nigeria over the years. 
However, significant impact has not been achieved in Nigeria in spite of various efforts put in place.

The country which operates a federal system of government with three tiers - local, state and the federal government has attempted in various ways to promote positive socio-economic and political changes. This is because, it is the responsibility of the government to encourage and improve the material requisites of well-being of the society in view of their economic status. This intention requires sincere efforts on designing policies and programmes aimed at some reforms in the area of institution, fiscal operation, management of macroeconomic variables, more employment of resources, improvement in education and training that is capable of raising living standard.

Efforts in the development of the region have been on going in view of the articulated National Development Plans of 1962-68, 1970-74, 1975$80,1981-85$ amongst others. Yet the economy is not measuring up vis-a-vis its contemporaries. In recent past, attention was given to poverty eradication due to the rating of Nigeria as one of the poorest economies as it was ranked between $130-154$ th position in the Global 172 economies and in spite of having large deposit of oil as it occupied a position of one of the world largest producer of crude oil (Guardian, 2005).

The poverty level is estimated at over $70 \%$ of the population notwithstanding the activities put in place over the years. This situation has been climaxed by the recent destruction of lives and property due to the activities of insurgence in the country. Disgustingly, EarthTrend (2003), points that the population of Nigeria living on less than $\$ 1$ per day is $70.2 \%$ while those living on less than $\$ 2$ each day are $90.8 \%$. This was when the exchange rate was about one hundred naira per dollar and the official price of a litre of fuel was N65. Presently, a dollar is overN470 in the parallel marketand the official pump price of a litre of fuel is above N145. The average Nigerians are really finding it difficult to have a meal instead of three square meal a day since the purchasing power has been drastically reduced by the prevailing economic quagmire and this has resulted to many abnormalities such as hunger, malnutrition, malnourishment and other poor health conditions that adversely retard over-all individual development and impedes living one's life span completely.

Nigerian population was estimated at 162 million by the World Bank (2011). An Economic Watch (2013) estimate of Nigeria population was 169, 282 million. In sub-Saharan Africa, Nigeria occupies about $20 \%$ of total population. But the growth rate of the population is at variance with the rate of food production, which compelled the country to import. The cost of imported food is not easily affordable by the poor, leading to malnutrition, hunger and mental retardation among others.

The poverty milieu has worsened with the activities of the 'Boko Haram' terrorist group in the North-Eastern states of Nigeria where 270 girls were abducted from their school dormitory and many towns and villages sacked within the last four to five years, adding to the increasing number of internally displaced persons (IGP) in Nigeria. Also, the activity of the Niger-Delta Militants in the South-South region of the country adversely impacted on the crude-oil production and the exploitation. This has led to a sharp decline in foreign exchange earnings. The situation deteriorated due to plummetion of international oil prices to below 30 USD per barrel in the early 2016.

The adaption of the floating exchange rate in 2016 amidst the stoppage of official foreign exchange allocation for imports of 41 consumer goods saw consumer price index (CPI), which is the measure of inflation in Nigeria, rose up to $18.55 \%$ in the last quarter of 2016 from single digit figure recorded in early 2015 .

As a result, Nigeria as a major import dependent nation lacked enough foreign exchange resources to import consumer and capital goods for poverty reduction and radical economic development. 
In view of this ugly episode in Nigeria over the years in spite of actions taken by the leaders, it is our intention to investigate a more practical approach to poverty reduction in Nigeria considering the success stories of other countries such as Malaysia, China and South Korea. In this regard, the paper is streamlined thus: section two focuses onpoverty in Nigeria some facts and statistics; government actions aimed at poverty alleviation is the section three, successful stories in reducing poverty: a comparative analysis is the section four; while section five is policy recommendations for Nigeria and conclusion.

\subsection{Poverty in Nigeria: Some Facts and Statistics}

Every leader in Nigeria has been aware of the high degree of poverty and the problem of 'growthlessness' in Nigeria and has put some actions directly or indirectly to change the trend but yet much has not been achieved. Actually, every problem has its solutions beside in consideration of the law of polarity - good and bad, problems and solutions and so on. Poverty has persevered in spite of all actions because the country has not applied the right and sustainable approaches that are specific to the economy. Besides, implementation and monitoring of poverty alleviation efforts have not been effective to enable desired results.

Poverty is really multidimensional as it encompasses a lot of things which retards the ability of one to live life fully and enjoy living. It includes lack of basic necessity of living, insecurity, lack of access for essentials and supporters of life. However, the United States Statement on poverty (June 1988), states "poverty is a denial of choices and opportunities, a violation of human dignity. It means lack of basic capacity to participate effectively in society. It means not having enough to feed and clothe a family, not having a school or clinic to go to; not having the land on which to grow one's food or a job to earn one's living, not having access to credit. It means insecurity, powerlessness and exclusion of individuals, households and communities. It means susceptibility to violence, and it often implies living on marginal or fragile environments, without access to clean water or sanitation".

Actually, the above are the part and parcel of the ailments and features of what is obtainable in Nigeria. There is denial of opportunity and choice of work, education, place of settlement andregular violation of human right by the leaders and the people. The average populace is not fully empowered to have a say on issues and policies affecting them. Inability to secure enough to feed self and family members have resulted to upsurge of different forms of crimes such as obtaining by tricks, robbery, corruption, ritual killing, kidnapping, prostitution amongst others. The situation compelled few Nigerians to accept being refugees in another country even when there is no war.In addition, the land ownership system cut-off many Nigerians from access to land for farming or erecting a living batcher and embargo on public sector employment in some establishments, poor infrastructure, non-conducive environment for business activity, epileptic power supply, lack of portable water, low investment in the country gave rise to inability to secure a job or delve into business so as to generate income to improve living standard. Besides, no bank credit facilities to assist indigent students or local entrepreneurs who want to improve education or business venture. Hence, the people of the country are caught up in the vicious circle of poverty.

The economy is dualised into rural and urban areas, and poverty exists in each but dominants in the rural area which harboured a large proportion of the population. National Survey of poverty as published by National Bureau of Statistic (2005) showed the national incidence of poverty rose between 1980-85 and 1992 to 1996. 
Table 1: Trends in Poverty Levels 1980-200

\begin{tabular}{|l|l|l|l|}
\hline \multicolumn{1}{|c|}{ Year } & \multicolumn{1}{|c|}{ Poverty Incidence } & \multicolumn{1}{|c|}{$\begin{array}{c}\text { Estimated Total } \\
\text { Population in million }\end{array}$} & $\begin{array}{c}\text { Population in } \\
\text { poverty } \\
\text { in million }\end{array}$ \\
\hline 1980 & 28.1 & 65 & 18.26 \\
1985 & 46.3 & 75 & 34.73 \\
1992 & 42.7 & 91.5 & 39.07 \\
1996 & 65.6 & 102.3 & 67.11 \\
2004 & 54.4 & 126.3 & 68.70 \\
\hline
\end{tabular}

Source: National Bureau of Statistic (2005)

Table 1 shows the persistent rise in poverty incidence, high population growth and poverty situation. The period of poverty increase coincide with the military leadership. Although the poverty incidence declined slightly in 2004 due to the activities of civilian government that commenced in 1999 nevertheless, the expected low poverty remains a mirage because of fiscal indiscipline, shortsightedness, nepotism, favouritism, corruption and greed.

Table 2: Poverty in Urban and Rural Sectors (1980-2004)

\begin{tabular}{|l|l|l|}
\hline Year & Urban & Rural \\
\hline 1980 & 17.2 & 28.3 \\
1985 & 37.8 & 51.4 \\
1992 & 37.5 & 46.0 \\
1996 & 58.2 & 69.3 \\
2004 & 43.2 & 63.3 \\
\hline
\end{tabular}

Source: National Bureau of Statistic (2005)

Table 2 depicts the dominance of poverty situation in the rural area due to uneven development of the two sectors in spite of the fact that the larger proportion of the population reside in the rural area. This situation has led to incessant rural-urban movement; thereby brought about population density in the urban cities with attended pressure on social amenities, insufficient accommodation, frictional/disguise unemployment, crimes amongst others. Succinctly, the exodus of rural skilled people with their talents and ingenuityto urban area means creation of a vacuum which the cumulative causation helps to perpetuate poverty in the rural area.

Table 3: Showing Zonal Poverty Trends, (19802004)

\begin{tabular}{|c|c|c|c|c|c|}
\hline Zone & 1980 & 1985 & 1992 & 1996 & 2004 \\
\hline South South & 13.2 & 45.7 & 40.8 & 58.2 & 35.1 \\
South East & 12.9 & 30.4 & 41.0 & 53.5 & 26.7 \\
South West & 13.4 & 38.6 & 43.1 & 60.9 & 43.0 \\
North Central & 32.2 & 50.8 & 46.0 & 64.7 & 67.0 \\
North East & 35.6 & 54.9 & 54.0 & 70.1 & 72.2 \\
North West & 37.7 & 52.1 & 36.5 & 77.2 & 71.2 \\
\hline
\end{tabular}

Source: National Bureau of Statistics (2005)

Table 3 reveals poverty trends in the six geopolitical zones in Nigeria. North Central, North East and North West data showed high level of poverty over the years in spite of government efforts. Intuitively, it can be pointed that the poverty situation must have risen in the northern part of the country in recent past and 
presently in view of the activities of insurgence and frequent religious crises that have led to the destruction oflives, cash crops, buildings; disruption of economic activities, mayhem and crisis that have brought about high unemployment, relocation of entrepreneurs who moved with skills, capital assets and other resources thereby creating cumulative

Table 4: Selected Macroeconomic Variables 1990-2014

\begin{tabular}{|c|c|c|c|c|c|c|}
\hline Variables & 1990 & 1995 & 2000 & 2005 & 2010 & 2014 \\
\hline Saving & 29.65 & 108.49 & 385.19 & $1,316.96$ & $5,954.26$ & $12,008.21$ \\
Av Manuf. Capacity Utilisation & 40.3 & 29.9 & 36.1 & 54.8 & 56.22 & 57.2 \\
Inflation rate & 7.36 & 72.8 & 6.93 & 17.86 & 13.72 & 8.06 \\
Domestic Investment & 40.12 & 141.92 & 331.06 & 804.4 & 4012.92 & 3523.43 \\
Interest Rate & 18.5 & 13.5 & 13.5 & 13 & 6.13 & 12.5 \\
Unemployment Rate & 5.4 & 7.5 & 13.1 & 11.9 & 21.1 & 7.8 \\
\hline
\end{tabular}

Sources: National Bureau of Statistics (2011); IMF World Economic Outlook, April 2013; CBN (2012 \& 2014); Kneoma.com/atlas/Nigeria/Unemployment rate; www.indexmundi.com/facts/nigeria/inflation

Table 4 depicts the state of few macroeconomic variables buttressing the status of Nigeria economy which contributes to poverty situation. Scholars have asserted that capital formation requires savings which is needed for investment and acquisition of capital over heads. Savings in Nigeria is low not suitable for a population of over 170 million. Low saving gives rise to low capital formation, low investment, low productivity, low income, hence the economy is gripped in the vicious circle of poverty. Investment figures show a relative rise but it is not befitting of thepopulation and this has made high unemployment at all times in Nigeria. A corollary to this is decline in average manufacturing capacity utilization. There is high insufficiency of industries that can absorb primary products and add enough values; this made Nigeria to rely so much on imported goods, hence resulting to balance of payments disequilibrium. The country is endowed with a lot of resources but lack the needed capital and physical investment to effectively harness it. Insufficient industries due to lack of capital has brought low average manufacturing capacity use. Although the figures show a considerable increase over the period but it is low in view of the quantum of idle resources in the country. This is why the country focuses so much on primary products and so low employment of resources and low income base. In addition, the purchasing power of the people is thwarted by dominantly double digit inflation rate over the years due to insensitivity of the resources managers, application of western policies not suitable for a developing nation and fiscal recklessness. The real incomes of the people are severely damnified by this regular rise in prices of 
goods and services, which has played enormous role to affect the consumption pattern and the living standard of the people. Unemployment rate is relatively high compared to some countries in Africa. Interest rate in Nigeria is uniform for all sectors, which does not encourage preferred sectors development. Cost of capital is high where available. Small and medium scale industries do not find it easy accessing investment funds due to the existing interest rate and lack of essential factors such as water supply, power supply and raw materials.

These situations have persistently retarded economic development and as such make it difficult for the populace to have enough to satisfy hunger. Physiological needs of man are yet to be addressed in Nigeria. Adequate attention needed in environmental restructuring, industrial revival and quality human capital development are far-fetched. Disgustingly, Nigerian leaders travel to other parts of the world and see progress and better things for themselves but unwilling to bring them to change Nigeria. Instead, they pay regular visits to developed and advanced economies at high cost to the society.

\subsection{Government Actions Aimed At Poverty}

\section{Alleviation}

However, Nigeria as a developing country has been really worried by the prevailing poverty situation, and has put varieties of programmes indirectly and directly to curb the menace such as the National Accelerated Food Production programme and the Nigeria Agricultural and Co-operative Bank under the implementation of Agricultural Development Projects(ADP) instituted in 1972 by Gen.Yakubu Gowon; Operation Feed the Nation (OFN) and Agricultural Guarantee Scheme fund made by Gen. Obasanjo in 1976 and Free Compulsory Education (FCPE) of 1977; President ShehuShagari's Green Revolution of 1979 and Low Cost Housing Scheme; Gen Buharia's Go-back-to land programme of 1983; Gen. Babangida's mass mobilization approach to poverty which incorporated Integrated Rural Development(IRD) and basic needs strategies and so on, targeted on increasing agricultural yield, reducing unemployment and illiteracy. Yet poverty has remained very high.

A study by Ogwumike (2002) showed that some of the policies and programmes put in place prior to Structural Adjustment Programme (SAP) were not actually directed at poverty alleviation but hoped to play a role. The conscious intention to pursue poverty goals is associated with Structural Adjustment Programme (SAP) from 1983 to 1993, during the military regime of President Ibrahim Babangida. 
International Journal of Trend in Scientific Research and Development, Volume 1(4), ISSN: 2456-6470 www.ijtsrd.com

Table 5 Summary of Actions Aimed at Poverty Reduction

\begin{tabular}{|c|c|c|c|}
\hline Programme & Year Established & Target group & Nature of Intervention \\
\hline $\begin{array}{l}\text { Directorate for Food, } \\
\text { Roads and Rural } \\
\text { Infrastructures } \\
\text { (DFRRI) }\end{array}$ & 1986 & Rural Areas & $\begin{array}{l}\text { Feeder Roads, rural } \\
\text { water supply and } \\
\text { rural electrification. }\end{array}$ \\
\hline $\begin{array}{c}\text { National Directorate } \\
\text { of } \\
\text { Employment (NDE }\end{array}$ & 1986 & $\begin{array}{l}\text { Unemployed } \\
\text { your }\end{array}$ & $\begin{array}{l}\text { Training, finance } \\
\text { and guidance. }\end{array}$ \\
\hline $\begin{array}{l}\text { Better Life } \\
\text { Programme } \\
\text { (BLP) }\end{array}$ & 1987 & Rural women & $\begin{array}{l}\text { Self - help and rural } \\
\text { development } \\
\text { programmes, skill } \\
\text { acquisition and } \\
\text { health care. }\end{array}$ \\
\hline $\begin{array}{c}\text { People's Bank of } \\
\text { Nigeria }(\mathrm{PBN})\end{array}$ & 1989 & $\begin{array}{c}\text { Underprivileged } \\
\text { in } \\
\text { rural and urban } \\
\text { areas }\end{array}$ & $\begin{array}{l}\text { Encouraging savings } \\
\text { and credit facilities }\end{array}$ \\
\hline $\begin{array}{l}\text { Community Banks } \\
\text { (CB) }\end{array}$ & 1990 & $\begin{array}{c}\text { Rural residents, } \\
\text { micro enterprises } \\
\text { in } \\
\text { urban areas }\end{array}$ & Banking facilities. \\
\hline $\begin{array}{c}\text { Family Support } \\
\text { Programme (FSP) }\end{array}$ & 1994 & $\begin{array}{c}\text { Families in Rural } \\
\text { areas }\end{array}$ & $\begin{array}{l}\text { Health care delivery, } \\
\text { child welfare, youth } \\
\text { development, etc. }\end{array}$ \\
\hline $\begin{array}{c}\text { Family Economic } \\
\text { Advancement } \\
\text { Programme (FEAP ) }\end{array}$ & 1997 & Rural areas & $\begin{array}{l}\text { Credit facilities to } \\
\text { support the } \\
\text { establishment of } \\
\text { cottage industries. }\end{array}$ \\
\hline
\end{tabular}

Source: Oladeji and Abiola, (1998).

At the initial stage of each of the programmes, it was considered great as it focused on groups considered poor in Nigeria. But could not be sustained due to the peculiarity of the economy; coupled with macroeconomic distortions, inconsistent policies, nepotism, selfishness of operators and corruption which retarded goal attainment. Quite worrisome is that in spite of all the efforts, poverty has been on the increase. It was pointed out that even at the period when Nigeria witnessed economic growth; considerable poverty reduction was not achieved. Between 1985 and1992, gross domestic product (GDP) rose slightly, although aggregate poverty headcount level came down a little, but there was high level of inequality and the poor did not enjoy in the economic progress since the depth and severity of poverty could not significantly change ( Obadan, 2002; Uma et al , 2013).

Actually, large chunk of human and physical capital were sunk into the programmes, but poverty reduction is still unattainable. Consequently, at the assumption of office by the civilian President Obasanjo in 1999, he intensified action on poverty reduction through promotion of agriculture, education, water supply and 
health services. Among the programmes he the realization of the SevenPoints' Agenda will go a introduced were: National Poverty Eradication long way to alleviate poverty in Nigeria and raise the Programme (NAPEP) which came up in 2001 that living standard of the people. Unfortunately, focused on absolute poverty eradication; the National significant impact was not achieved. The real income Poverty Eradication Council (NAPEC) was of the people have remained very low, virtually all established to coordinate the programme with various organisations that was associated with poverty reduction. Some government ministries earmarked as core poverty alleviation ministries based on the Joda Panel and Abdullahi Committee Reports. Furthermore, poverty alleviation institutions were also identified. Therefore, activities for NAPEP were classified thus: Youth empowerment Scheme (YES), Rural Infrastructure Development Scheme (RIDS), Social Welfare Service Scheme (SOWESS) and National Resources Development and Conservation Scheme (NRDCS). From all indication, each scheme focused on specific areas of supplies of basic needs, facilities and infrastructure aimed at empowering the youths and the populace with the ulterior motive to address poverty. Poverty Reduction Strategy Paper (PRSP) was the next move under the supervision of the Economic Policy Coordinating Committee (EPCC) in the office of the Vice President. A National core team was inaugurated in February, 2001 (FRN, 2000; Obadan, 2002; Ogwumike, 2002; Igbuzor, 2004; Uma et al, 2013).

Nevertheless, various activities continued by other leaders that succeeded Obasanjo. For instance Ola(2009) points out that the President Yar'Adua Seven Points Agenda includes power and energy, food security, wealth creation, transport sector, land reforms and security and education. It was hoped that

\section{Successful Stories in Reducing Poverty: A}

\section{Comparative Analysis}

Nigeria is not the only poor countries in the world. Many other countries that were at par with Nigeria have gone so far and better placed with respect to living standard. Different policies, strategies, approaches, activities and huge expenditure have been made by the country, yet the rise in poverty has been 
persistent. Other countries have done related activities and actions aimed at alleviating poverty and were able to have effective reduction of poverty over the years. What lessons are there for the country to learn and adopt?

\subsection{An Overview of Malaysia's Poverty Reduction} Approach

Malaysia gradually transformed from poor nation to middle income nation which is poverty reduction success.Hatta and Ali (2013) pointed that in the quest to tackle poverty given countries poverty specifics, Malaysia had to design its own poverty line in the 1970 s at the period the government was seriously concerned with efforts to revert the high poverty status. Malaysia is a multiethnic society just like Nigeria but with a population of about 25 million people and the major ethnic groups include the Malays, Chines and Indians, The country faced with some crisis which compelled the elites to come up with measures and programme strictly enforced to achieve a development height. The emergence of the New Economic Policy (NEP) in 1971 which was aimed at resolving some socio-economic quagmire was the genesis of resolving the low development status. The initial intention of the two main aim of the NEP was to tackle poverty regardless of ethnicity and the set target was to bring down poverty from $49.3 \%$ of households in 1970 to $16.7 \%$ in 1990 for Peninsular Malaysia. In the urban-rural target was reduction from $58.7 \%$ and $21.3 \%$ in 1970 to $23 \%$ and $9.1 \%$ by 1990 respectively. The country aimed at reducing high incidence of poverty due to low living standard. The second issue of poverty reduction focused on employment creation in agriculture, secondary and tertiary sectors for the indigenous people which involved the restructuring of employment and ownership of capital in the corporate sector. Target was made and great achievement realized (Warr, 2000; Kinuthia, 2010)

Besides, the leaders of the nation, therefore, employed the poverty line to examine the minimum consumption needs of an average household for food, housing, clothes and non-food requirements. Consequently, in 1970, the existing poverty level of $49.3 \%$ decreased to 8.1 in 1999 . By 2000 , it stood at $5.5 \%$. Besides, hard core poverty came down from $1.2 \%$ in 2004 to $0.7 \%$ in 2009 and the overall incidence of poverty came down to $5.7 \%$ in 2004 to $3.8 \%$ in 2009 . However, the overall poverty rate stood at 3.7\% (Department of Statistics Malaysia, 2011)

In consideration of the status of some vulnerable regions in Malaysia; the country targeted on more inclusive approach, which involved the application of economic development model. This involved capacity building and expanded implementation that was geared toward the alleviation of socio-economic inequalities, and also offering subsidies to the needy. The two goals in aspiring for inclusiveness approach were: (a) enabling equitable chances for all, and (b) making available a social safety net for the disadvantaged groups. This requires emphasis on equitable access to health, education and basic infrastructure. A follow upwas the enhancement of income support in view of the phased out of subsidies. Specifically, the two outstanding features of social 
policy in Malaysia vis-a vis other nations are (i) the consistence and orderliness of social policies and additional development due to conducive environment and prolonged period of stability, and (ii) the perseverance and resilience of the successive government cum the high degree of commitment of the public sector to raise the standard of living of the people of Malaysia (Hatta and Ali, 2013).

The country Malaysia understood where they were and where they wanted to be, and had to make every reasonable, reliable policies and programmes with a good focus which brought remarkable changes that the entire people of the economy were happy with and worthy of emulation. The adoption of adequate macroeconomic and fiscal policies that were properly managed helped greatly to revive a poor country to a better one. Sufficient monitoring of policy and programme implementation helped to ensure direction of all resources earmarked for poverty alleviation.

\subsection{An Overview of China's Poverty Reduction} Strategy:

The country is highly populated with profound poverty situation and aspired seriously to change the trend through adequate actions. Like most other poor countries, China has rural and urban areas with poverty dominant in the rural area (World Bank, 2000). Rounds of poverty reduction came in the mid1980s. The initial round was from 1986 to 1993 while the second round was from 1994 to 2000. Available statistics showed that the poor population fell in the 1990s. Those identified as poor fell from 85 million in 1990 to 32 million in 2000. Rural poverty headcount declined from 9.5 in 1990 to 3.4 in 2000. Undoubtedly, a large scale poverty alleviation programmes was established by Chinese government in 1994 referred to as 8-7 Plan which was aimed at promoting local economic development involving public investments target in form of giving subsidized credits, earmarked budgetary grants and 'Food-forWork projects'. The programmes were broadly designed to take care of a good proportion of the populace. A huge sum of money was spent since the programme cost from 1994 to 2000 was RMB 1240 billion (ie \$14.9 billion) (Wang, 2005)

In the first round of poverty alleviation, it was quite visible of the high poverty status of the people which lead to the launching of anti-poverty programme in the mid-1980s. The established body inter-ministerial Leading Group was set up in 1986 to oversee the realization of the programme. The Leading Group was able to identify 258 counties as National Poor Counties on the basis of mixed set of poverty line and those with rural net per capita below 150 yuan were termed as poor. The awareness of uneven distribution of poverty across counties gave rise to more attention in areas with the greatest of need with respect to spending the limited funds. The planners were concerned on encouraging economic development and revenue raising activities. The adopted measure also involved ranking of counties based on gathered information referred to as rural net income per capita. On yearly basis, the statistics department randomly selected about 100 rural households and informed the selected sample to keep records of their expenditures 
and revenues. It is from the aggregate statistics that calculation of rural net income per capita was done which formed a major source of official statistics used by the Chinese government in assessing rural welfare and related policy making. However, the programme was able to capture a good size of the poor but political actions made it to face some criticisms ( Park and Wang, 2001; Park et al, 2002; Meng, 2013)

Reacting to the criticism in first round of poverty alleviation programme, the Leading Group transformed the poverty line and so in 1992, poor counties were those with rural net income per capita below 400 Yuan. However, due to reactions emanating from previous categories of poor counties, the central government raised the poverty line to 700 Yuan for counties termed as poor prior to 1993 and so 592 counties were labeled as National Poor Counties. A good number of the counties, about one third fell under the poor group showing over $72 \%$ of the rural poor. The newly identified poor counties in 1993 and the follow up development support are called the 87Plan.

The Leading Group played great roles headed by the most senior government officer. Provision for reward and punishment such as demotion was made for local government officials engage in implementing activities. The emphasis was strict compliance to goal achievement. This implies guarding against any form of corruption. The three major interventions for the 87 Plan for poverty alleviation includes credit support for targeted counties issued through the People's Bank of China (Apex Bank) to provincial Agriculture Bank of China that in turn channel funds to its branches. The subsidized annual interest for loans was $2.88 \%$ and in 1996 a good proportion of the loans were concentrated on rural enterprises. The name 8-7 Plan shows the focus of action which the main aim concerns increasing the greater proportion of the 80 million poor above the government's poverty line within a period of seven years( $\mathrm{Li}$ and Zhou, 2005; Meng, 2013).

The poor counties were also given budgetary grants by the Ministry of Finance. The Leading Group was still overseeing and directing activities. Funds were transmitted through the county bureaus that administered the final disbursement in collaboration with respective sectoral county government departments. The fund was titled 'Poor Area Development Funds' used in productive construction of projects. In addition, budgetary grants earmarked or assigned for basic education, health care among others were also provided.

It was also put in place public employment projects known as Food-for- Work in selected areas which was focused on long term improvement of the poor areas involving land transformation and the building of basic infrastructure such as public utilities, good road net-work among others.

The programme also offered short-term support to the poor with respect to jobs creation. The central government issued out coupons and not cash to relevant local planning commissions for settlement of physical inputs of production and labour. The central and provincial authorities decide on the forms of investment and allowed county governments to select 
sites, and village committees were in-charge of allocation for project investment and the mobilization of labour at the right time. This approach helped to control and monitor aggregate cash circulation so as to check-mate inflation as well as being conscious of who does what. The poor counties were not operating at same level of poverty and as such treatment to each was on same intensity accordingly.

In addition to various other poverty reduction activities, fiscal reform centred on human capital development. Mai (2011) pointed out that since March 2006, free compulsory education was implemented for all and living allowance for poor boarding students was also made. These raised government expenditure considerably. The state council came up with the regulation of pre-school education in November 2010 and also pinpointed the general rules of public welfare and universal access with the intention of achieving desirable impact. In other to promote health of the people rural medical and health services at county, town and village levels were established at a subsidized cost in order to encourage effective and efficient basic public health services delivery to the poor. In poor areas, Reduction of Maternal Mortality and Elimination of Neonatal Tetanus programme was implemented in 2001 in poor areas aimed at reducing young children mortality rate by two-third in 2015 Millennium Development Goal. Supplement drugs such as folic acids were freely distributed to rural women since 2009 aimed at assisting the health of the newborns in the rural areas. Undoubtedly, China concentrated poverty reduction efforts in virtually all the crucial areas and locations known to help reduce poverty incidence. Jobs and employment creation is essential for efficient economic activity required to boost output production and income generation. The establishment of functional physical and human capitals were vigorously pursued. Specifically, the channel of resources distribution and control is a thing worthy of emulation, and the attention to human capital development from very early stage and subsidized medications to the poor played enormous role in repositioning poverty.

\subsection{An Overview of Republic of South Korea's Poverty Reduction Strategy}

Just like other Third World countries, a large proportion of the South Korean people were living in absolute poverty. In the mid-1960s, PSPD/UNDP (2000) noted that between $60-70 \%$ of the population was living in poverty. The country experienced serious hunger and deprivation due to destruction of the environment during the Korean War of 1950-53. They were not able to meet their basic minimum needs such as food, cloth and shelter. The country was expected to remain impoverished and have absolute poverty for a long time, but within a short span, as pointed by Park (2001) absolute poverty dramatically fell so low to $3.4 \%$ of the population. The situation was a surprise turn around to all other economies.

Correspondingly, the fall in income poverty tantamount to the benefits realised in human capital improvement. Consequently, as pointed out by the World Bank (1999), life expectancy rose from 55 in 
1962 to 72 in 1998, infant mortality declined from 7\% in 1992 to $0.9 \%$ in 1998 . UNDP(2000) states that the human development index rose to 0.854 and was ranked the $31^{\text {st }}$ in the world by 1998 .

Republic of Korea (South Korea) gradually metamorphosed to improved living standard which stemmed from the actions and roles of the government directed to economic growth. This intention brought about positive reduction which is reflected in the living standard of the people vis-à-vis other contemporary poor societies. Rauch and Evans (2000); Henderson et al(2002) posit that among the factors that gave rise to South Korea extraordinary growth position since the late 1960s is effective governance abilities and capabilities that includes bureaucratic competence. Emphasis on restructuring the economy and poverty reduction does not only stem from industrialization. Rather since early 1970s to late 1990 s poverty alleviation intention has gone hand in hand with the activities of the government with respect to economic growth aspiration without much effort on specific anti-poverty policies. Poverty alleviation in this case is the outcome of economic growth which was internationally advertised by the World Bank and other agencies.

The remarkable advancement of the country in spite of all odds is partly attributed to its early land reform in the late 1940s, inclusive of a strategy of successful export-oriented industrialization in the 1960 s to 1970 . The peasantry got land directly and indirectly due the Agricultural Land Reform Amendment Act of March 1950. This action on the part of the leaders empowered the people with respect to increased agricultural practices and employment of labour. The provision of loan repayment with a proportion of the annual crop output by the rural farmers was a welcome development that encouraged effective participation in agriculture. Government devised approach of selling its annual stock of rice at a controlled price and channeled the funds to pay the former landlords of their land properties. Besides, land was sold at a very low price by the owners as determined by the government which played a role in the distribution of income. Besides, poverty reduction positively changed due to 1967-71economic development plan pursued by the government. Import substitution was also adopted. The government led by President Park Jung Hee promoted the substitution of the imported cement, refined oil, fertilizer among others with local production (Henderson et al 2002; Jeon and Kim 2000). This action created a lot of investment, employment and effective resources utilisation. Interestingly, (OECD) pointed that a good proportion of the people $28.8 \%$ was self-employed. This to a great extent lowered unemployment rate.

Korean Gross Domestic Product (GDP) per capita, a measure of growth in the 1960s, was very low compared to most countries. From the actions of the government, it was pointed by African Development Bank(2010) that Korean Gross Domestic Product (GDP) per capita rose from US\$130 in 1954 to about US\$ 19,115 in 2008 and was adequately shared in the economy. The implementation of an export oriented infant industry strategy played significant role in transforming the economy from an underdeveloped 
country to a developed one. Just like most underdeveloped countries, Korea was dominantly rural, with a big informal sector. Worthy of mention in Korean development efforts is the tax reforms in $1960 \mathrm{~s}$ and 70s. Initially, attention was given on raising revenue collection and supporting growth based on revising tax policies, which involved merging certain number of taxes, increasing the share of indirect taxes and employing tax incentives to assist chosen sectors. However, the decline in revenue generation led to efficient implementation of policies. So, tax administration was strengthened from 1966 to 1974. Rapid growth of revenue was experience from the creation of the National Tax Service. From197480 the relevance of equity as a goal of tax policy rose and Value Added Tax was put in place. Remarkably, the Tax reforms enabled Korean revenue to greatly increase from 9\% of GDP in 1966 to $15 \%$ in 1980. Given a fall in government expenditure, Korea was able to attain fiscal balance which was priority strategic intention.

Suffice it to mention that Korean success story can be attributed to focusing its tax policies on few priority which fully aligned with national development strategy; and broadening its tax base through effective tax administration, that ensured operational empowerment and performance accountability. Besides is the approving of targets and effective monitoring of tax.

\subsection{Policy Recommendations for Nigeria}

Life is filled with varieties of events and lessons. A wise man is he who easily emulates the positive actions leading to achieving success like others, and who also guards against witnessing the ugly experiences of others .The success stories of nations can be a motivating factor for other nations. The indirect and direct poverty reduction intentions of Nigeria since after independence has been devoid of proper implementation, monitoring and corrupt practices. Resources allocation toward programmes and strategies for tackling poverty were often diverted due to the corrupt tendency of officials responsible to ensure their uses. Consequently, in spite of huge budgetary and actual allocations for poverty alleviation over the yearsin Nigeria, the rise in poverty has been persistent. Given this scenario, it is utmost important that we make the following recommendations based on the success stories of Malaysia, China and South Korea for a refocus of poverty alleviation strategy in Nigeria. On this note, the following points will help to reduce poverty situation in Nigeria.

(i)Nigeria government has to practically, sincerely and seriously determine to tackle poverty as was done by the Malaysian government and designits own absolute poverty line accordingly with respect to the poverty status of all the geopolitical zones. Targets to be achieved with a specific period of time must be made at the onset and also create employment opportunities using tax incentive and monetary policy instruments. In addition, the environment has to be repositioned to attract both domestic and foreign 
investment. Actions are also needed to encourage practical and effective access to health, education and basic infrastructure, since low level of infrastructure hampers growth and economic development. Nigeria has to build more on infrastructure to mitigate the huge gap existing in the sector. This will reinforce productivity in the real sector; raise income and jobs through increase in aggregate investment. Realistic subsidies and a cheap interest rate have to be given to preferred sectors so as to impact on income of the rural farmers and entrepreneurs just like the Malaysian's government did to its citizens.

(ii)Just like China, poverty is dominant in rural Nigeria and so, it has to adopt rounds of attack on povertylike China such as 2017-2023 and 2024-2029 in the first and second rounds respectively, and pursue it vigorously. Local or rural development strategy involving massive investment in the rural areas has to be embarked upon and sufficiently monitored. This requires instituting effective and efficient monthly and evaluating mechanisms. Poor areas ranked according to absolute poverty line, and poverty statistics must be generated from ranked areas as sample for evaluation. The calculated poverty line will be the basis for determining rural net income per capita. Budgetary allocation granted for credit support for production, education and health with special interest rate on loan. Fund allocation channeled to the appropriate rural farmers and entrepreneurs through the Central Bank of Nigeria (CBN), Bank of Industries (BOI) and other agencies for financial assistance will involve the use of coupon and not cash. The Leading Group has to implement, supervise and monitor all activities from beginning to end.In addition is the empowerment of individuals for investment and public employment project created in both agro-industries and manufacturing sector.

(iii) Besides industrialisation like South Korea, Nigeria has to embark on land reform, tax reform and import substitution including establishing export oriented infant industries. It is necessary for Nigeria to domestically produce a good number of food items and products usually imported so as to create jobs for the unemployed and increase output production. It is disgusting to see Nigeria importing tooth-pick and most other foods items which were exported in the early 1960 s and 70s. There is urgent need for Nigeria to effectively use the endowed fertile soil. Nigeria has not effectively harnessed the resources of palm fruits which is a good source of income for Malaysia who got palm fruits from Nigeria in the recent past.

Finally, Nigeria needs to shun all forms of corrupt practices, invest massively on education, health and infrastructure in both the rural and urban areas. There is need for adequate implementation of programmes, strategies and policies on poverty reduction and economic development. The ways of doing things over the years have to change henceforth. Really the country needs a positive change that culminates to infrastructural repositioning, enhance actions that will put adequate food on the table of the people, encourage economic activity, good governance, attitudinal change on work and ethics, separate religion from governance, increasing resources utilisation, reforming institutions, improving quality 
human capital, tackling corruption, industrialisation among others as a panacea for poverty alleviation.

\section{Conclusion}

The chapter has shown poverty situation and poverty reduction efforts in Nigeria. It has equally shown the actions and activities adopted by Malaysia, China and South Korea in the bid to overcome poverty situation. Poverty in Nigeria can be drastically reduced. People's circumstances and low living standard brought about by the way things have been in Nigeria can be changed for better if the right steps capable of turning around situations are taken and consistently monitored. The recommendations of this study are expected to reduce poverty in Nigeria if adequately implemented. But it involves honesty, sincerity and sufficient political will to surmount poverty at all cost. Good leaders having broad hearts and element of radicalism are needed now. It equally necessitates adjusting the institutions of the government capable of eradicating all forms of corruption.

\section{Reference}

Addison, T. and G.A. Cornia( 2001). Income Distribution Policies for Faster Poverty Reduction. Discussion Paper No. 2001/93, World Institute for Development Economic Research (UNU/WIDER), Helsinki.

Canagarajah, S.J., G. Ngwafon and S. Thomas (1997). The Evolution of Poverty and Welfare in Nigeria, 1985-1992. Policy Research Working Paper No. 1715

Central Bank of Nigeria (2012). Statistical Bulletin, Vol 23, Abuja, CBN

Central Bank of Nigeria (2014). Statistical Bulletin, Vol 25, Abuja, CBN
Departments of Statistics Malaysia. (2011). Monthly Statistical Bulletin. Retrieved from http://www.statistics.gov.my

EarthTrends.(2003). 'Economic Indicator-Nigeria,' retrieved on July 20, 2013 from http://earthtrends.wri.org.

Economic Watch (2013). 'Nigeria Economic Statistics and Indicators,' Retrieved on October 29, 2013 from http://www.economywatch.com/economic-

Statistics/country/Nigeria/

Federal Republic of Nigeria(FRN) (2000). Obasanjo's Economic Direction 1999-2003. Lagos: Down Functions Nigeria Ltd.

Federal Government of Nigeria (FGN) (2014). Key Economic Achievement of President Goodluck Jonathan in the South West Geo-political Zone (20102014), Office of the Chief Economic Adviser to the President

Hatta, Z and Ali, I (2013).Poverty Reduction Policies in Malaysia: Trends, Strategies and Challenges Asian Culture and History;. 5, (2), 48-56

Henderson, J, Hulme, D, Phillips, R and Kim, E.M (2002) Economic Governance and Poverty Reduction in South Korea, Globalisation \& Poverty

Igbuzor, O (2004). 'Poverty Eradication and Public Policy in Nigeria,' Alternative Poverty Reduction Strategy for Nigeria, Centre for Democracy and Development, 46.

International Monetary Fund (IMF) (2013). World Economic Outlook, April

Jeon, Y.-D. and Kim, Y.-Y. (2000). 'Land Reform, Income Redistribution, and

Agricultural Production in Korea'. Economic Development and Cultural Change 48(2): 253-268.

Kinuthia, B. K (2010). 'Poverty Reduction in Malaysia', Africa Studies Centre, Leiden University, The Netherlands 
Kneoma.com/atlas/Nigeria/Unemployment rate;

Kanbur, R. and N. Lustig, (1999). Why is Inequality Back on the Agenda? Paper Prepared for the Annual Bank Conference on Development Economics, World Bank Washington DC., April 28-30.

Kolenikov, S. and A. Shorrocks, (2003). A Decomposition Analysis of Regional Poverty in Russia. Discussion Paper No. 2003/74. World Institute for Development Economic Research (UNU/WIDER), Helsinki.

Li, H and Zhou, L., (2005). Political Turnover and Economic Performance: the Incentive Role of Personnel Control in China. Journal of Public Economics 89 (9-10), 1743-1762.

Mai, L. (2011). Poverty Eradication in China: A New Phase. China Development Research Foundation

Meng, L (2013). 'Evaluating China's Poverty Alleviation Program: A Regression Discontinuity Approach,' Journal of Political Economic 101, 1-11.

National Bureau of Statistics (2005). Poverty Profile for Nigeria, Abuja: Federal Republic of Nigeria.

National Bureau of Statistics (2011). Unemployment, Abuja: Federal Republic of Nigeria.

Obadan, O. M. (2002). 'Poverty Reduction in Nigeria. The Way Forward' CBN Economic and Financial Review, 39(4).

OECD (2000), Pushing Ahead with Reform in Korea: Labour Market and Social Safety-net Policies. OECD.

Ogwumike, F. O. (2002). 'An appraisal of poverty reduction strategies in Nigeria', Central Bank of Nigeria Economic and financial review, 39(4).

Oladeji, S. I. and Abiola A. G. (1998). 'Poverty Alleviation with Economic Growth Strategy: Prospects and Challenges in Contemporary Nigeria,' Nigerian Journal of Economic and Social Studies (NJESS), 40(1).
Ola, R (2009) Yar'Adua's Seven Point Agenda: Any Hope for the Nigerian people? Retrieved on November 24, $2016 \quad$ from http://www.marxist.com/yaraduas-seven-pointagenda-nigeria.htm

Park, N.-H. (2001), 'Poverty Rate and Poverty Line in Korea'. Conference Paper, Philippine Institute for Development Studies, April.

Park, A., Wang, S., (2001). China's Poverty Statistics. China Economic Review 12 (384C39).

Park, A., Wang, S., Wu, G., (2002). Regional Poverty Targeting in China. Journal of Public Economics 86 (1), 123-153.

PSPD/UNDP (2000). Poverty Status and Monitoring of Korea in the Aftermath of the

Financial Crisis. People's Solidarity for Participatory Democracy and the United

Nations Development Programme. PSPD/UNDP.

Rauch, J. and Evans, P. (2000), "Bureaucratic Structures and Bureaucratic Performance in Less Developed Countries". Journal of Public Economics 75(1): 49-71.

Transparency International (2011).'Corruption Perception Index'. Retrieved on May 13, 2013 from http://www.transparency.org/cpi2011/results

Transparency International. (1996). 'Corruption Perception Index'. Retrieved on May 13, 2013, from http://www1.gwdg.de/ uwvw/rank-96.htm

Transparency International.(1997). 'Corruption Perception Index' Retrieved on May 13, 2013, from http://www1.gwdg.de/ uwvw/rank-97.htm

Transparency International (2009). 'Corruption Perception Index.' Retrieved on May 13, 2013, from 'http://archive.transparency.org/policy_research/surve ys_indice/cpi/2009/cpi_2009_table 
Transparency International (2010).'Corruption

Perception Index'. Retrieved on May 13, 2013 from

http://www.transparency.org/cpi2010/results

The Guardian Newspaper (2005), 'Governance and

Challenges of Poverty,' Lagos: The Guardian

United States Statement (June 1988). Retrieved from http://wwww.helium.com/items/1587576-poor-

service-delivery.

UNU/WIDER (2000). United Nations University/ World Institute for Development Economic Research, World Inequality Database, Vol. 10, Helsinki.

Uma, K.E, Eboh, F.E, Obidike, P.C, Ogwuru, H.O.R (2013) Poverty, Underdevelopment and Emerging Economies: Nigeria in Focus,' Global Journal of Management and Business Research Finance 13 (6), 25-32 www.indexmundi.com/facts/nigeria/inflation

UNDP (2000), Human Development Report 2000, New York and Oxford, Oxford University Press.

Wang, S., (2005). Poverty targeting in the People's Republic of China. In: Weiss, J. (Ed.), Poverty Targeting in Asia. Edward Elgar, Cheltenham, United Kingdom.

Warr, P.G. (2000).'Poverty Incidence and Economic Growth in South East Asia' Journal of Asian Economics 11: 431-441.

World Bank (1999), World Development Report 1999/2000: Entering the 21st Century, New York and Oxford, Oxford University Press.

World Bank, (2000). China: Overcoming Rural Poverty. World Bank, Washington, D.C.

World Bank (2011) 'Nigeria: Development Indicator. Retrieved on May 11, 2013, from www.worldbank.org.

World Bank (2012) 'Nigeria: Development Indicator. Retrieved on May 11, 2013, from www.worldbank.org. 